\title{
Islamic Social Reporting and Financial Distress In List of Sharia Securities
}

\author{
Utari Evy Cahyani \\ Padangsidimpuan State Islamic Institute, Indonesia \\ utari@iain-padangsidimpuan.ac.id \\ Misnen Ardiansyah \\ Sunan Kalijaga State Islamic University of Yogyakarta, Indonesia \\ misnen.ardiansyah@uin-suka.ac.id \\ Sunaryati \\ Sunan Kalijaga State Islamic University of Yogyakarta, Indonesia \\ sunaryati@uin-suka.ac.id
}

\begin{abstract}
The number of sharia-approved companies in the Indonesia Stock Exchange is growing rapidly. It is important to see how the social performance of these companies, using Islamic Social Reporting Index (ISR Index). Financial Distress as an early sign of a company's failure is also important to study. This study examines the relation between ISR Index and financial distress in list of sharia securities. The control variables apply in this research are SIZE, ROA, CR, WCTR, DER, and RETA. By using a sample of 129 companies from financial statements and annual reports (2014-2018), three models were built with the Modified Altmans Z-Score, Ohlson O-Score and Zmijewski Zm-Score as a proxy of financial distress. Based on ISR index calculation, the theme of products and services has the highest disclosure score. The lowest disclosure score is corporate governance theme. Panel data regression results show that ISR Index affects financial distress in the Modified Altman's model. It means the higher the ISR index value, the greater the likelihood of companies run into financial distress. Whereas in Ohlson's and Zmijewski's model, ISR Index has no effect on financial distress. Means relationship between ISR Index and Financial Distress (Ohlson's and Zmijewski's) is unexplainable by the model.
\end{abstract}

Keywords: Social responsibility, Corporate governance, Financial distress, Panel data.

\section{INTRODUCTION}

Since BAPEPAM-LK established a collection of sharia-approved companies in 2007 called List of Sharia Securities (Daftar Efek Syariah/DES)(OJK, n.d.), the number of issuers keep on increasing. Out of 600 issuers recorded in 2018, 399 issuers are included in the sharia-approved companies (Research and Development Division Indonesia Stock Exchange, 2018). Analyzing th 
IQTISHADIA financial distress of sharia-approved companies as an early sign of company 13,2 failure becomes important because more than half issuers in Indonesia Stock Exchange include in List of Sharia Securities.

Research on the prediction of corporate financial distress have been carried out with a variety of explanatory variables and methodological techniques. Started by (Beaver, 1966) using financial ratio with univariate discriminant analysis model to distinguish failing and non-failing companies. Then, (Altman, 1968) developed Beaver model using financial ratio with multiple discriminant analysis approach to predict a company's failure. Altman also made adjustments towards Z-Score model which had been built by Z'-Score and Z"-Score models that can be used not only for manufacturing companies (Altman, Iwanicz-Drozdowska, Laitinen, \& Suvas, 2017).

Ohlson found that there's limitation in using multiple discriminant analysis in assuming normality and group distribution (Ohlson, 1980). Then Zmijewski with his probit model developed distress prediction using three variables. But the critics toward the static technique of financial distress prediction was also done as continuation of research on financial prediction model (Zmijewski, 1984). Financial distress prediction models which were popularized by Altman, Ohlson, and Zmijewski are traditional models which can be used as early warning signs for financial distress.

Research on financial distress in Indonesia needs to be done seeing that Indonesia Stock Exchange data recorded 21 companies delisting during 20132018 (OJK, 2019). Delisting can be an indicator that the company's financial performance has decreased. Therefore, it is important to know whether a company is experiencing financial distress or not, as an early warning of company's failure.

In other hand, Corporate Social Responsibility (CSR) can reduce financial distress better for non-state-owned enterprises compared to stateowned enterprises in China (Shahab, Ntim, \& Ullah, 2019). Positive CSR activity significantly decrease company's financial distress. This negative correlation happens in mature companies (Al-Hadi, Chatterjee, Yaftian, Taylor, \& Monzur Hasan, 2019).

Based on Sharia Enterprise Theory, in addition to being responsible to stakeholders, a company is also responsible to God by agreeing to His provisions. Based on this theory (Sharia Enterprise Theory), this research uses the concept of Islamic Social Reporting (ISR) as an embodiment of the performance of corporate social responsibility. There are five themes of 
ISR disclosure index such as finance and investment, product and service, employee, society, and environment (Haniffa, 2002). The theme of good governance was added to complete the previous ISR component (Othman, Thani, \& Ghani, 2009a).

Because of the limited research on the correlation between ISR and financial distress, this study analyzed the correlation between ISR and financial distress in Daftar Efek Syariah. The paper is organized as follows. The next sections reviews some theoretical foundations and literature review. Following it, discuss the research methods employed to analyze the data: sample selection and data collection, research variables, calculation of financial distress, estimation of ISR index, and panel data regression. The next section presents the empirical result of this study and discussion. Finally, concluding remarks and limitation of the research as the last section.

\section{LITERATURE REVIEW}

Grand Theory used in this study was Agency Theory, Stakeholder Theory, and Legitimacy Theory. This study also used Sharia Enterprise Theory to explain Islamic Social Reporting as a research variable. Theory about financial distress's also explained to establish hypotheses in this study.

\section{Agency Theory}

An agency relationship arises when two or more parties where one is appointed as an agent, that is the party acting on behalf of the other party who appoints, namely principals, in a particular area related to the matter of the decision (Ross, 1973). Agency Theory developed by Jensen and Meckling was used to understand the correlation between business principal (shareholder) and agents (company's management party). The agent is the party that manages the company for example managers and the board of directors who act as decision makers in running the company. While the principal is the party that evaluates the information provided by the agent (Jensen \& Meckling, 1976).

In agency theory, it is explained that each party has different interest. Where management has an interest in maximizing profits by pursuing projects or short-term investments, shareholders want the maximum welfare for him that can be achieved through projects or long-term investment. One of the ways to overcome this conflict of interest is to monitor the agent through corporate governance (McColgan, 2001). 
IQTISHADIA

13,2

160

\section{Stakeholder Theory}

Stakeholder is a group or individual that can affect or be affected by an achievement of organizational goals. Stakeholder Theory explained the relation between corporate as an analysis unit with an individual or group that affect or get affected by said business (Freeman, 2010). The implication of this theory form accountability point of view according to Gray et al. is that a company has an obligation to account for (not only financial statements) actions that are the responsibility of the company (Gray, Owen, \& Adam, 1996). In line with Gray et al., Van der Laan Smith et al. explained that stakeholder theory is the basis for corporate social disclosure obligations and their application in different companies in various countries (Laan, Adikhari, \& Tondkar, 2005).

\section{Legitimacy Theory}

Legitimacy Theory is usually used in literature to discuss social and environtment report. Although modestly, it is often used to explain company's social and environmental disclosure policy. Company legitimacy is obtained when there are similarities between the results and what is expected by the society from the company, therefore, there is no demand from society. A company can do social act as a reflection of company's consideration towards society (Deegan, Rankin, \& Tobin, 2002). Based on Legitimacy Theory, the company should convince the society that its activities and performance are acceptable to the community. Companies can use their annual reports to illustrate the impression of social and environmental responsibility that has been carried out.

\section{Sharia Enterprise Theory}

Sharia Enterprise Theory stated Allah as the center for everything. Human as God's creature has consequence to submit to all of His law (Meutia, 2010). Based on this theory, economic power is not only on one party, but on many parties, in other words, many stake holders are involved. From sharia enterprise theory's point of view, wealth distribution or value-added does not only apply to the people who are involve directly in a business or to parties who give their contributions to the company, for example: stakeholders, creditor, employee, and government. Other parties who are indirectly involved in the business done by the company, or the parties who don't give any financial or skill contribution should also get the distribution of added value (Triyuwono, 2001). 
Sharia enterprise theory principle gives the main form of accountability to God (vertical) which is then translated into the form of accountability (horizontal) to the human race and the natural environment. The manifestation of horizontal accountability is the existence of addedvalue distribution towards two groups which are the parties who are directly involved with the business (Direct Participants) and the parties who are not directly involved with the business (Indirect Participants). Direct participant consists of: shareholders, management, employees, creditors, suppliers, government. While Indirect Participants consist of: mustahiq (recipients of zakat, infaq, and sadaqah) and the natural environment (for example for nature conservation) (Triyuwono, 2001).

\section{Financial Distress}

When a business is experiencing a decline to the point where the company cannot meet financial obligations, the company enters financial distress (Baldwin \& Mason, 1983). The first sign of said condition is usually the existence of unpaid debt or dividend reduction. Some companies which experience difficulties went bankrupt while some others recovered and overcame the problem they're facing (Altman, 1968). A company experiencing financial distress which at first only in the form of not able to pay the debt, if it's not solved well the company can go into bankruptcy, liquidation, and even confiscation of assets.

Financial distress categorize into two perspectives based on theoretical analysis and empirical study. From theoretical perspective, financial distress has different degrees. Mild financial distress is in the form of temporary cash flow difficulties, while severe financial distress is business failure or bankruptcy. Whereas from empirical study perspective, financial distress is defined as a situation which is clearly showing the financial difficulty of a company, just like bankruptcy theory based on constitution. The studies on financial distress in the past explored variables which can classify distress into mild, moderate, or bankrupt category. While recent studies consider a single criterion of financial distress (Sun, Li, Huang, \& He, 2014).

\section{Islamic Social Reporting and Financial Distress}

Bad management is the main determinant factor for financial distress (Gordon, 1970). This bad management is mirrored in how a company tells information to the public. Sharia category companies are also expected to deliver company performance information that also takes into account
Islamic Social Reporting and Financial Distress 
IQTISHADIA responsibilities to Allah SWT, to stakeholders (consumers, employees, and 13,2 the community), as well as responsibilities to the natural environment. A company with high Islamic social reporting value indicates that the company is well managed. Said company should have less probability to experience financial distress. Based on the theories explained earlier, the hypothesis of this study is that Islamic Social Reporting negatively affect Financial Distress.

\section{RESEARCH METHOD}

\section{Sample Selection and Data Collection}

The population in this study includes all companies in List of Sharia Securities in December 2018. The total population is 399 companies. The number of samples is determined by Krejcie and Morgan table for determining sample size from a given population (Krejcie \& Morgan, 1970). The number of samples based on the table is 196 companies that was randomly selected. Because this study uses data for 2014-2018, the companies that have been randomly selected then reduced by the companies listed above in 2014, the incomplete data, and suspended companies. So the final sample size is 129 companies. The type of data applied in this research is secondary data. The research uses financial statements and annual reports published by the company starting in 2014-2018.

\section{Dependent Variable: Financial Distress}

Financial distress is the dependent variable in this study. This study uses three financial distress measurement models, namely the Modified Altman Z-Score model (Altman et al., 2017), the Ohlson O-Score model (Ohlson, 1980) and the Zmijewski Zm-Score model (Zmijewski, 1984). The Modified Altman model and the Ohlson model are used because they have a good degree of accuracy in the case of companies in Indonesian capital market (Syamni, Majid, \& Siregar, 2018). The Zmijewski model is good for predicting financial distress in emerging markets (Ashraf, G. S. Félix, \& Serrasqueiro, 2019). The models are each defined in Appendix I.

Z-Score values are grouped into three categories, namely distress, gray, and health. If the Z-Score is less than 1.1, the company is included in the distress category. If the Z-Score is between 1.1 and 2.6, the company is in the gray category. Meanwhile, the Z-Score is more than 2.6, the company is included in the health category. O-Score values are also grouped into three categories, namely distress, gray, and health. If the O-Score is more 
than 0.38 , the company is included in the distress category. If the O-Score is Islamic Social equal to 0.38 , the company is in the gray category. Meanwhile, the O-Score is less than 0.38 , the company is included in the health category. In other Reporting and hand, Zm-Score values calculated by the formula above are grouped into two categories, namely distress and health. If the $\mathrm{Zm}$-Score value is more than $\mathrm{o}$, the company is included in the distress category. If the Zm-Score value is less than $\mathrm{o}$, the company is included in the health category.

\section{Independent Variable: ISR Index}

Islamic Social Reporting Index (ISR Index) is an independent variable in this study. The ISR index was developed to measure the level of ISR of companies listed on the Stock Exchange. There are 43 statement items in 6 themes namely finance and investment, products/services, employees, community, environment (Haniffa, 2002) and corporate governance (Othman et al., 2009a) to estimate ISR Index. The ISR index variable is calculated by the content analysis method (Klaus Krippendorff, 2004) of the company's annual report. Each item gets 1 if there is disclosure in the annual report and gets 0 if there is no disclosure about it. If all items are disclosed in the financial statements, the maximum score is 43 .

The relationship between the ISR Index and financial distress is generally expected to be the opposite direction. This means that the higher the ISR index, the lower the financial daistress. However, because of this study using three models that have different characters, the interpretation will be different. In Ohlson and Zmijewski's model, the relationship between ISR and financial distress is in the opposite, means the higher the ISR Index, the lower the O-Score and Zm-Score values. Whereas in the Altman model, the relationship between ISR and Financial Distress is in the same direction. It means the higher the ISR Index, the higher the Z-Score values.

\section{Control Variable}

Control variables used in this research include company size (SIZE), Return on Assets (ROA), Current Ratio (CR), Working Capital Turnover Ratio (WCTR), Debts to Equity Ratio (DER) and Retained Earning to Total Assets (RETA). SIZE is measured by the natural logarithm of Total Assets. Company size is used to control differences in resources, ability to deal with competitors, and opportunities to get funding. Based on previous research, companies that are more likely to have greater ability to overcome financial distress than small companies (Al-Hadi et al., 2019). 
IQTISHADIA

13,2

164

ROA is measured by comparing net income with total assets. CR is measured by comparing current assets to current liabilities. WCTR is measured by comparing revenue with working capital. RETA is measured by comparing retained earnings/retained earnings with total assets. Based on previous research, the four control variables are positively related to financial (Al-Hadi et al., 2019; Imelda \& Alodia, 2017; Pranowo, Achsani, Manurung, \& Nuryartono, 2010). Whereas DER which is measured by comparing total debt with total equity is negatively related to financial distress (Murni, 2018).

\section{Regression Model}

The regression model used in this study is panel data regression with 5 years data from 2014-2018 and the number of companies is 129. This study uses three model of panel data regressions. The panel data equation used in this study are:

FD $(\text { Modified Altman } Z-S \text { core })_{i t}=\beta_{0}+\beta_{1} I S R$ Index $_{i t}+\beta_{2}$ SIZE $_{i t}+\beta_{3} R O A_{i t}+$ $\beta_{4} C R_{i t}+\beta_{5} W C T R_{i t}+\beta_{6} D E R_{i t}+\beta_{7} R E T A_{i t}+\varepsilon_{i t}$

$F D(\text { Ohlson } O-\text { Score })_{i t}=\beta_{0}+\beta_{1} I S R$ Index $i t+\beta_{2} S I Z E_{i t}+\beta_{3} R O A_{i t}+\beta_{4} C R_{i t}+$ $\beta_{5} W C T R_{i t}+\beta_{6} D E R_{i t}+\beta_{7} R E T A_{i t}+\varepsilon_{i t}$

$F D(\text { Zmijewski Zm-Score })_{i t}=\beta_{0}+\beta_{1} I S R$ Index $_{i t}+\beta_{2} S I Z E_{i t}+\beta_{3} R O A_{i t}+\beta_{4} C R_{i t}+$ $\beta_{5} W C T R_{i t}+\beta_{6} D E R_{i t}+\beta_{7} R E T A_{i t}+\varepsilon_{i t}$

Where i represent Companies (1-129), t represent Year (2014-2018), $\beta_{\mathrm{o}}$ is a constant, $\beta_{1-} \beta_{7}$ are coefficient, FD (Modified Altman Z-Score, Ohlson O-Score, Zmijewski Zm-Score) is proxy of financial distress, ISR Index is Islamic Social Reporting Index, SIZE is Ln Total Assets, ROA (Return on Assets) represent Net Income/Total Assets, CR (Current Ratio) represent Current Assets/Current Liabilities, WCTR (Working Capital Turnover Ratio) represent Revenue/Working Capital, DER (Debt to Equity Ratio) represent Total Liabilities/Total Equity, RETA is Retain Earning/Total Assets, and $\varepsilon$ is error term. This research uses significance level (a) $5 \%$. 
In this study, to estimate the parameters with panel data, there are Islamic Social three techniques namely the Common Effect Model (CEM), the Fixed Effect Model (FEM), and the Random Effect Model (REM). In CEM, the parameter estimation is combining time series and cross section data as one unit without looking at time and individual differences. The approach used in CEM is Ordinary Least Square (OLS). In contrast to CEM, in FEM assumed that the Financial Distress intercepts of each individual are different while the slope between individuals is fixed. FEM technique uses dummy variables to capture differences between intercepts between individuals. Whereas in REM assumed that each individual has different intercepts, where these intercepts are random or stochastic variables. The REM technique takes into account that errors may correlate across cross sections and time series (Widarjono, 2018).

There are three techniques for selecting the appropriate panel data model. First, the F statistical test (Chow Test) is used to choose between CEM and FEM. The null (Ho) hypothesis in this test is Common Effect Model. While the alternative hypothesis (H1) is Fixed Effect Model. If the probability is smaller than alpha (0.05) then Ho is rejected, which means the selected model is FEM. Second, the Hausman test is used to choose between FEM and REM. The null hypothesis (Ho) in this test is Random Effect Model. While the alternative hypothesis (H1) is Fixed Effect Model. If the F probability of the Hausman test results is greater than alpha (0.05) Ho is rejected, which means the REM model is better. Third, the Lagrange Multiplier (LM) test is used to choose between CEM and REM. The null hypothesis (Ho) in this test is Common Effect Model. Whereas the alternative hypothesis (H1) is Random Effect Model. If the Breush-Pagan probability value is less than alpha (0.05) then Ho is rejected, which means the chosen model is REM (Widarjono, 2018).

\section{RESULTS}

\section{Variable Description}

The results of the research on the financial distress prediction of 129 companies included in the List of Sharia Securities using the Modified Altman Z-Score model, the Ohlson O-Score model, and the Zmijewski Zm-Score model have different characters. There are only 2 companies that are predicted in the same category for each model for 5 years namely JKSW which is predicted into the financial distress category by all three models. MTSM which is predicted into the health category by all three models. 
IQTISHADIA

13,2

166

Figure 1 describe calculation of financial distress predictions using Modified Altman Z-Score, the Ohlson O-Score, and the Zmijewski ZmScore model. The Modified Altman Z-Score model predicts 85 companies (65.89\%) are health, 28 companies (21.75\%) are gray, and 16 companies (12.40\%) are identified in financial distress category in 2014. In 2015, 72 companies (55.81\%) are health, 32 companies (24.81\%) are gray, and 25 companies (19.38\%) are identified in the financial distress category. In 2016, 85 companies (65.89\%) are health, 20 companies (15.50\%) are gray, and 24 companies (18.61\%) are identified in financial distress category. In 2017 , 82 companies (63.57\%) are health, 23 companies (17.83\%) are gray, and 24 companies (18.61\%) are identified in the financial distress category. Whereas in 2018, 78 companies (60.47\%) are health, 29 companies (22.48\%) are gray, and 22 companies (17.05\%) are identified in the financial distress category.

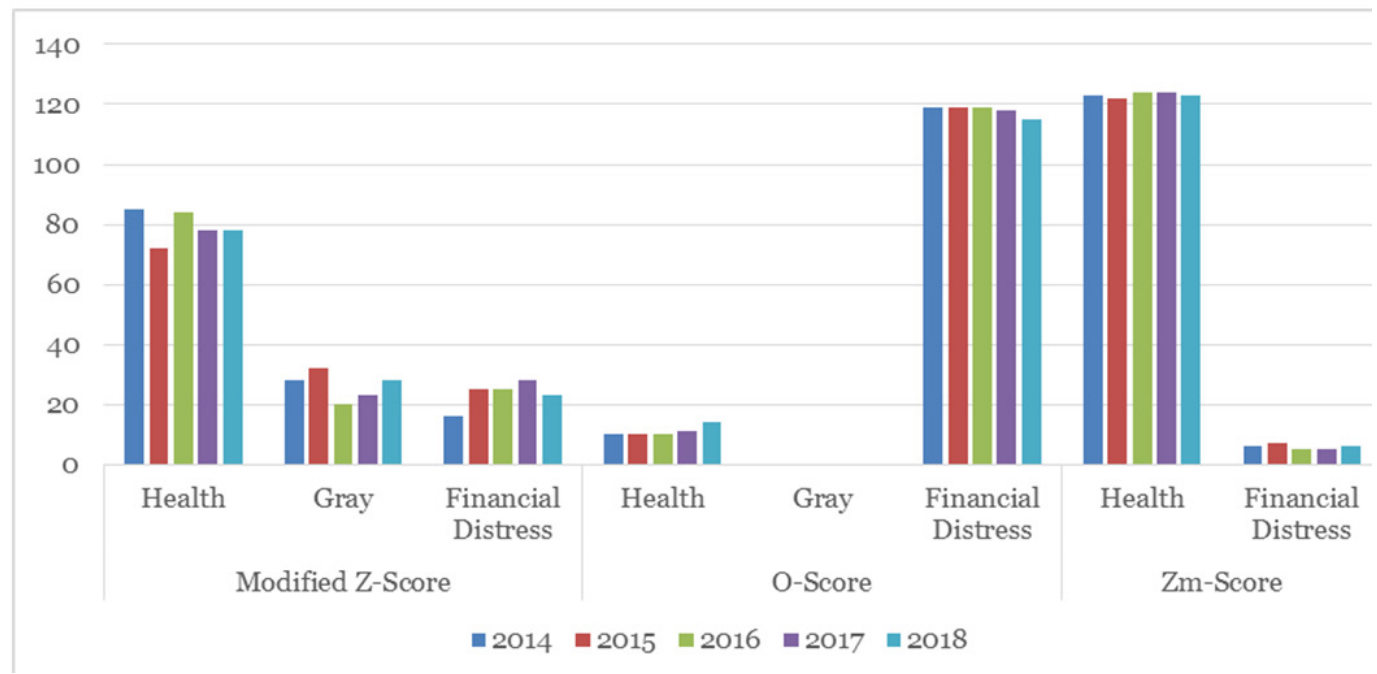

Figure 1. Financial Distress Prediction

Figure 2 explains the disclosure average scores in the ISR Index for each theme. Based on ISR index calculation from 129 companies in 2014-2018, products/services theme has the highest average score of $67.0 \%$, followed by community, financial and investment, environment and employee themes. While the lowest disclosure score is corporate governance theme at $42.8 \%$. 


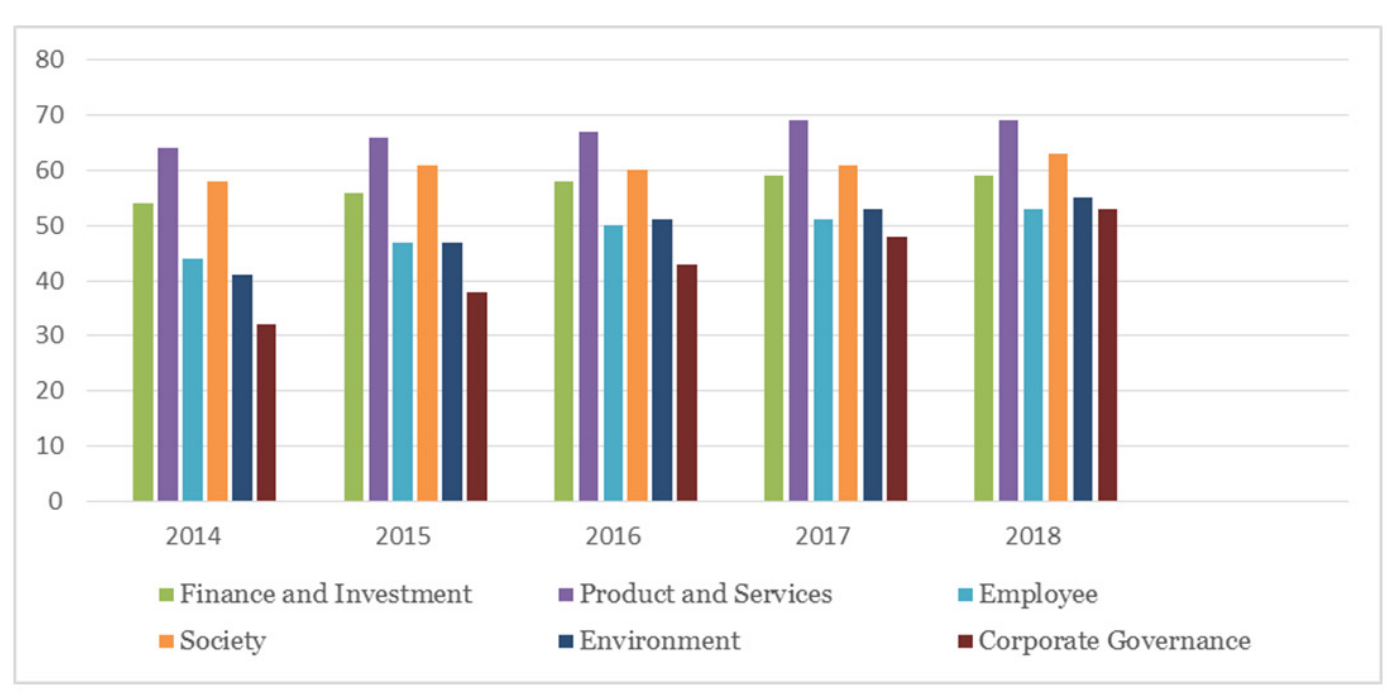

Islamic Social

Reporting and

Financial Distress

Figure 2. The Disclosure Average Scores in the ISR Index

The descriptive statistical results of this study are in Table 1. Based on Table 1, the highest Z-Score is 119.67 and the lowest is -7.07 and the average is 4.40. The median Z-score is 3.40, which means more companies are included in the health category. Because of the Z-Score limit for the health category is 2.60. The highest and lowest O-Score values are 17.60 and -6.31 with an average of 2.43 .

Table 1. Descriptive Statistic

\begin{tabular}{lrrrrrr}
\hline \multicolumn{1}{c}{ Variable } & N & \multicolumn{1}{c}{ Mean } & \multicolumn{1}{c}{ Median } & \multicolumn{1}{c}{ Max } & \multicolumn{1}{c}{ Min } & \multicolumn{1}{c}{ Std. Dev. } \\
\hline Z-Score & 645 & 4.3987 & 3.3988 & 119.6596 & -7.0703 & 6.5137 \\
O-Score & 645 & 2.4326 & 2.4062 & 17.6046 & -6.3121 & 1.8547 \\
Zm-Score & 645 & -1.8939 & -1.9262 & 11.9362 & -5.5196 & 1.6290 \\
ISR Index & 645 & 54.2059 & 53.4884 & 86.0465 & 20.9302 & 13.8020 \\
SIZE & 645 & 28.7344 & 28.6754 & 32.3092 & 24.9208 & 1.5568 \\
ROA & 645 & 0.0247 & 0.0286 & 0.6101 & -0.7348 & 0.0866 \\
CR & 645 & 2.4534 & 1.5534 & 49.7784 & 0.0000 & 3.7649 \\
WCTR & 645 & 20.6756 & 2.3954 & 10058.2300 & -579.5112 & 401.7358 \\
DER & 645 & 0.4514 & 0.4467 & 2.8602 & 0.0082 & 0.2676 \\
RETA & 645 & 0.1342 & 0.1757 & 3.2600 & -2.1997 & 0.3948 \\
\hline
\end{tabular}

The median O-Score is 2.41, which means more companies are included in the financial distress category. This is because the O-Score limit for the financial distress category is greater than 0.38. The highest and lowest $\mathrm{Zm}$-Score values are $\mathbf{1 1 . 9 4}$ and $\mathbf{- 5 . 5 2}$ while the average is $\mathbf{- 1 . 8 9}$. The median value of $\mathrm{Zm}$-Score is -1.93 , meaning that the sample companies are more in 
IQTISHADIA

13,2 the health category. This is because the $\mathrm{Zm}$-Score for the health category is smaller than 0 .

The average value of the ISR Index is $54.21 \%$. While the highest ISR index value is $86.05 \%$, namely PNBS in 2017 which is included in the financial industry. The lowest value is $20.93 \%$, namely BAYU in 2014 which is included in the trade, service and investment industries. ISR index value of close to $100 \%$ indicates that the company has reported sharia social responsibility reporting.

\section{Model Selection in Panel Data}

Before estimating the relationship between the financial distress and ISR index, we need to evaluate first which panel regression model (CEM, FEM or REM) is the most suitable model to estimate the relationship by using the Chow test, Haussmann test and LM test. Table 2 describe output of panel data selection model of ISR Index and Financial Distress.

Table 2. Test Results of Panel Data Model Selection of ISR Index and Financial Distress

\begin{tabular}{ccccccc}
\hline Test & \multicolumn{2}{c}{ Panel A } & \multicolumn{2}{c}{ Panel B } & \multicolumn{2}{c}{ Panel C } \\
\hline Prob. & Result & Prob. & Result & Prob. & Result \\
\hline Chow Test & o,oooo & FEM & o,oooo & FEM & 0.0000 & FEM \\
\hline Hausman Test & o,oooo & FEM & o,oooo & FEM & 0.4816 & REM \\
\hline LM Test & & & & & 0.0000 & REM \\
\hline
\end{tabular}

The Chow Test results of Panel A show that the probability value is $0.0000<0.05$, so the FEM model is better than the CEM model. Meanwhile, the Hausman Test results of Panel A show that the probability value is 0.0000 $<0.05$, so the FEM model is better than the REM model. The results of Chow Test for Panel B show that the probability value is $0.0000<0.05$, so the FEM model is better than the CEM model. Meanwhile, the Hausman Test results of Panel B show that the probability value is $0.0000<0.05$, so the FEM model is better than the REM model. Based on Chow Test results of Panel C, the probability value is $0.0000<0.05$, so the FEM model is better than the CEM model. Meanwhile, the Hausman Test results of Panel C show that the probability value is $0.4816>0.05$, then the REM model is better than the FEM model. While the LM Test results of Panel $\mathrm{C}$ show that the probability value is $0.0000<0.05$, the REM model is better than the CEM model. 
Based on model selection, the most appropriate model for the ISR Islamic Social Index and Modified Altman Z-Score is Fixed Effect Model. Similar to that, the most appropriate model for the ISR Index and Ohlson O-Score is Fixed Reporting and Effect Model. On other hand the most appropriate model for the ISR Index and Zmijewski Zm-Score is Random Effect Model.

\section{Relationship between ISR Index and Financial Distress}

The next stage after model selection is the estimation of panel data model. Table 3 reports the regression results between ISR Index and Financial Distress. In Panel A, high value of modified Z-Score represent lower levels of distress. In other hand, high value of O-Score and $\mathrm{Zm}$-Score represent high levels of distress.

Table 3. Regression Results

\begin{tabular}{|c|c|c|c|c|c|c|}
\hline \multirow[t]{2}{*}{ Test } & \multicolumn{2}{|c|}{ Panel A } & \multicolumn{2}{|c|}{ Panel B } & \multicolumn{2}{|c|}{ Panel C } \\
\hline & Coef. & Prob. & Coef. & Prob. & Coef. & Prob. \\
\hline $\mathrm{C}$ & 15.531560 & 0.0002 & 1.119461 & 0.2029 & -4.3947100 & 0.0000 \\
\hline ISR Index & -0.010639 & 0.0324 & -0.001449 & 0.2358 & -0.0006890 & 0.1646 \\
\hline SIZE & -0.236371 & 0.1140 & -0.050411 & 0.0992 & 0.0033980 & 0.6565 \\
\hline $\mathrm{ROA}$ & 4.163268 & 0.0000 & -3.790732 & 0.0000 & -4.5535510 & 0.0000 \\
\hline CR & 0.400830 & 0.0000 & -0.012880 & 0.0716 & 0.0044370 & 0.0000 \\
\hline WCTR & 0.000012 & 0.7090 & 0.000056 & 0.0070 & 0.0000002 & 0.9781 \\
\hline DER & -11.276710 & 0.0000 & 6.500425 & 0.0000 & 5.6290180 & 0.0000 \\
\hline RETA & 15.531560 & 0.0000 & 0.223598 & 0.0090 & 0.0083340 & 0.5593 \\
\hline Adj & \multirow{3}{*}{\multicolumn{2}{|c|}{$\begin{array}{c}0.969250 \\
645\end{array}$}} & \multirow{3}{*}{\multicolumn{2}{|c|}{$\begin{array}{c}0.989414 \\
645\end{array}$}} & \multirow{3}{*}{\multicolumn{2}{|c|}{$\begin{array}{c}0.989215 \\
645\end{array}$}} \\
\hline R-Square & & & & & & \\
\hline $\mathrm{N}$ & & & & & & \\
\hline
\end{tabular}

In Panel A, the coefficient of determination (adjusted R-square) equation is 0.969250 , or $96.925 \%$. This value indicates that the variation of the Modified Altman Z-Score variable can be explained by the variation of the independent variables (ISR Index) and control variables (SIZE, ROA, CR, WCTR, DER, RETA) of 96.925\%, the rest is explained by other variables outside the research equation.

Based on the regression results for Panel A, the probability value for the independent variable (ISR Index) is $0.0324<0.05$, while the coefficient value is negative. This means that there is a negative influence between the ISR Index on Financial Distress which is proxied by the Modified Altman Z-Score. The probability value of the control variable, ROA, CR, and RETA are $0.0000<0.05$, and the sign of the coefficient is positive, which means that ROA, CR and RETA have a positive effect on Financial Distress proxied 
IQTISHADIA

13,2

In Panel B, the coefficient of determination (adjusted R-square) equation is 0.989414 , or $98.94 \%$. This value indicates that the variation of the Ohlson O-Score variable can be explained by variations in the independent variable (ISR Index) and control variables (SIZE, ROA, CR, WCTR, DER, RETA) of 98.94\%, the rest is explained by other variables outside the equation research.

Based on the regression results for Panel $\mathrm{B}$, the control variable probability value, WCTR, DER, and RETA $<0.05$, and positive coefficient sign, it means that WCTR, DER and RETA have a positive effect on Financial Distress as proxied by Ohlson O-Score. While ROA has a probability <0.05 and a negative coefficient sign, it means that ROA has a negative effect on Financial Distress which is proxied by Ohlson O-Score.

In Panel $\mathrm{C}$, the coefficient of determination (adjusted R-square) equation is 0.989215 , or $98.92 \%$. This value indicates that the variation of the Zmijewski Zm-Score variable can be explained by the variation of the independent variable (ISR Index) and the control variables (SIZE, ROA, CR, WCTR, DER, RETA) of $98.92 \%$, the rest is explained by other variables outside the equation research.

Based on the regression results for Panel $\mathrm{C}$, the control variable probability value, $\mathrm{CR}$ and DER $<0.05$, and positive coefficient sign, it means that CR and DER have a positive effect on Financial Distress as proxied by Zmijewski Zm-Score. While ROA has a probability $<0.05$ and a negative coefficient sign, it means that ROA has a negative effect on Financial Distress which is proxied by Zmijewski Zm-Score.

\section{DISCUSSION}

The relationship between ISR Index and Financial Distress analyzed using three financial distress models. ISR index negatively affects the Z-Score in the Modified Altman model. The results showed that the ISR Index has a negative effect on financial distress, it means that the higher the value of the ISR Index, the greater the possibility of companies experiencing financial distress. Even if we look at regression coefficient (-0.010639), it is a little impact. It means, if the ISR increases by $10 \%$ the Z-Score decreases by o.10639. This research imply that companies that make a good report about Islamic social performance still has financial distress risk. 
The research finding is not suitable with Fich \& Slezak research and Islamic Social Gordon's statement which states that poor management, in this case is indicated by the ISR Index value, is a major cause of company failure, which Reporting and in this study is indicated by financial distress (Fich \& Slezak, 2008; Gordon, 1970). Based on Sharia Enterprise Theory, the concept of Islamic Social Reporting (ISR) as an embodiment of the performance of corporate social Financial Distress responsibility. This findings not in line with research by Al-Hadi et al. which states that total corporate social responsibility (CSR) has a positive effect on Z-Score (Al-Hadi et al., 2019).

Based on the regression result, ISR Index has no effect on financial distress in Panel B and C. That means relationship between ISR Index and Financial Distress (proxied by Ohlson O-Score and Zmijewski Zm-Score) is unexplainable. If we assume that Islamic Social Reporting (ISR) as an embodiment of the good corporate governance, this research in line with Pranowo et al. that good corporate governance have no significant impact on corporate financial distress (Pranowo et al., 2010). To the best of author's knowledge, research on the relationship is very limited. Accordingly this model need further testing using other objects.

SIZE as a control variable has no effect on financial distress for all three panels. It means, company size has no impact on financial distress in this research. This contradicts the research of Al-Hadi et al. which states that SIZE has a negative effect on financial distress (Al-Hadi et al., 2019). Other research explain that SIZE has an impact to Islamic Social Reporting (Othman, Thani, \& Ghani, 2009; Putra \& Lubis, 2020; Qoyum, Mutmainah, \& Setyono, 2017; Sunarsih \& Dahlifah, 2020). The next studies may use ISR as a mediating variable between company size and financial distress.

ROA affects financial distress for all three panels but has a different mark. In the Altman model ROA has a positive effect on financial distress. Means that the higher the ROA the healthier the company. While the Ohlson and Zmijewski ROA models have a negative effect on financial distress. This has the same interpretation with Altman model, tha higher the ROA the smaller the financial distress risk. This finding reinforce Al-Hadi et al. findings (Al-Hadi et al., 2019).

$\mathrm{CR}$ as a control variable has a positive effect on financial distress in the Altman and Zmijewski models. That means, the more liquid the company is, the smaller the financial distress risk. This research in line with Pranowo et al. that explain CR has a positive effect on financial distress (Pranowo et al., 
IQTISHADIA

13,2

172

2010). While WCTR has a negative effect on financial distress only on Ohlson's model. Its imply that the more efficient the company the smaller the risk of financial distress. This research support Pal opinion (Shrabanti Pal, 2015).

Likewise, DER has an effect on financial distress for all three panels but has a different sign. The Altman DER model has a negative effect on financial distress. Means the higher the debt to equity ratio, the greater the risk of financial distress. Meanwhile the Ohlson and Zmijewski DER models have a positive effect on financial distress. That means, the higher the DER, the greater the financial distress risk. The findings in line with Noviandri research (Noviandri, 2014). Based on the results of the study, RETA has a positive effect on financial distress in the three panels. That means, even though the company has good profitability, it still has the risk of financial distress. Imelda and Alodia's findings in obedience to this research (Imelda \& Alodia, 2017).

\section{CONCLUSSION}

This research was conducted to investigate the relationship between the ISR Index and Financial Distress in companies included in the Sharia Securities Register. A total of 129 companies were randomly drawn from 399 companies in the Sharia Securities List in December 2018. By using three financial distress models namely Altman Z-Score Modification, Ohlson O-Score, and Zmijewski Zm-Score as the dependent variable and the ISR Index as the independent variables. In addition, control variables are also used namely SIZE, ROA, CR, WCTR, DER, RETA.

The results showed that the relationship between the ISR Index and financial distress can be explained through the Altman Z-Score Modified model. Because by using the Modified Altman Z-Score as the dependent variable, the ISR Index has a negative effect on financial distress. It means that the higher the value of the ISR Index, the greater the possibility of companies experiencing financial distress. ISR Index has no effect on financial distress in Ohlson and Zmijewski model. That means relationship between ISR Index and Financial Distress (proxied by Ohlson O-Score and Zmijewski Zm-Score) is unexplainable by the model. Accordingly this model need further testing using other objects. 


\section{LIMITATION}

This study has several weaknesses, first the sample is not differentiated into a healthy company and experiencing financial distress. Second, the ISR Index is calculated as the total items disclosed. The relationship of each theme from the ISR Index to financial distress needs to be done to see in more detail which theme is more influential. Further research on the association between the ISR Index and financial distress also needs to be done considering that there are still gaps in the results of the study.

\section{References}

Al-Hadi, A., Chatterjee, B., Yaftian, A., Taylor, G., \& Monzur Hasan, M. (2019). Corporate social responsibility performance, financial distress and firm life cycle: evidence from Australia. Accounting and Finance, 59(2), 961-989. https://doi.org/10.1111/acfi.12277.

Altman, E. I. (1968). Financial Ratios, Discriminant Analysis and the Prediction of Corporate Bankruptcy. The Journal of Finance, 23(4), 589-609. Retrieved from http://links.jstor.org/.

Altman, E. I., Iwanicz-Drozdowska, M., Laitinen, E. K., \& Suvas, A. (2017). Financial Distress Prediction in an International Context: A Review and Empirical Analysis of Altman's Z-Score Model. Journal of International Financial Management and Accounting, 28(2), 131171. https://doi.org/10.1111/jifm.12053.

Ashraf, S., G. S. Félix, E., \& Serrasqueiro, Z. (2019). Do Traditional Financial Distress Prediction Models Predict the Early Warning Signs of Financial Distress? Journal of Risk and Financial Management, 12(2), 55. https://doi.org/10.3390/jrfm12020055.

Baldwin, C. Y., \& Mason, S. P. (1983). The Resolution of Claims in Financial Distress the Case of Massey Ferguson. The Journal of Finance, 38(2), $505-516$.

Beaver, W. H. (1966). Financial Ratios As Predictors of Failure. Journal of Accounting Research, 4(Empirical Research in Accounting: Selected Studies (1966)), 71-111.

Deegan, C., Rankin, M., \& Tobin, J. (2002). An examination of the corporate social and environmental disclosures of BHP from 1983-1997: A test
Islamic Social

Reporting and

Financial Distress

173

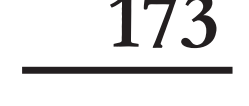


IQTISHADIA

13,2

174

of legitimacy theory. Accounting, Auditing \& Accountability Journal (Vol. 15). https://doi.org/10.1108/09513570210435861.

Fich, E. M., \& Slezak, S. L. (2008). Can corporate governance save distressed firms from bankruptcy? An empirical analysis. Review of Quantitative Finance and Accounting, 3O(2), 225-251. https://doi.org/10.1007/ s11156-007-0048-5.

Freeman, R. E. (2010). Stakeholder Theory: The State of Art. Cambridge: Cambridge University Press.

Gordon, M. J. (1970). American Finance Association Towards a Theory of Financial Distress. The Journal of Finance, 26(2), 347-356.

Gray, R., Owen, D., \& Adam, C. (1996). Accounting and Accountability: Changes and Challenges in Corporate Social and Environmental Reporting. London: Prentice-Hall.

Haniffa, R. (2002). Social Reporting Disclosure: An Islamic Perspective. Indonesian Management and Accounting Research, 1(2), 128-146.

Imelda, E., \& Alodia, C. I. (2017). The Analysis of Altman Model and Ohlson Model in Predicting Financial Distress of Manufacturing Companies in the Indonesia Stock Exchange. Indian-Pacific Journal of Accounting and Finance, 1(1), 51-63.

Jensen, M. C., \& Meckling, W. H. (1976). Theory of the firm: Managerial behavior, agency costs and ownership structure. Journal of Financial Economics, 3(4), 305-360. https://doi.org/10.1016/0304405X(76)90026-X.

Klaus Krippendorff. (2004). Content Analysis: An Introduction to Its Methodology. Sage Publications (2nd ed). Thousand Oaks: Sage Publication Inc. https://doi.org/10.1103/PhysRevB.31.3460.

Krejcie, R. V., \& Morgan, D. W. (1970). Determining Sample Size for Research Activities. Educational and Psychological Measurement, 30, 607610. https://doi.org/10.1261/rna.2763111.

Laan, S. J. Van der, Adikhari, A., \& Tondkar, R. H. (2005). Exploring Differences in Social Disclosures Internationally: A Stakeholder Perspective. Journal of Accounting and Public Policy, 24(2), 123-151.

McColgan, P. (2001). Agency Theory and Corporate Governance: A Review of The Literature From A UK Perspective. Working Paper No. o6/o203, Department of Accounting and Finance, University of Shrathclyde, UK. 
Meutia, I. (2010). Menata Pengungkapan CSR di Bank Islam (Suatu Pendekatan Kritis). Jakarta: Citra Pustaka Indonesia.

Murni, M. (2018). Analisis Faktor-Faktor Yang Mempengaruhi Tingkat Financial Distress Pada Perusahaan Manufaktur Yang Terdaftar Di Bei Tahun 2010-2014. JURNAL AKUNTANSI DAN BISNIS : Jurnal Program Studi Akuntansi, 4(1). https://doi.org/10.31289/jab. v4i1.1530.

Noviandri, T. (2014). Peranan Analisis Rasio Keuangan dalam Memprediksi Kondisi Financial Distress Perusahaan Sektor Perdagangan. Jurnal Ilmu Manajemen, 2(4), 1655-1665.

Ohlson, J. A. (1980). Financial Ratios and the Probabilistic Prediction of Bankruptcy. Journal of Accounting Research, 18(1), 109. https://doi. org/10.2307/2490395.

Othman, R., Thani, A. M., \& Ghani, E. K. (2009a). Determinants of Islamic Social Reporting Among Top Shariah-Approved Companies in Bursa Malaysia. Research Journal of International Studies, 12(October), 4-20.

Othman, R., Thani, A. M., \& Ghani, E. K. (2009b). Determinants Of Islamic Social Reporting Among Top Shariah -Approved Companies In Bursa Malaysia. Research Journal of International Studies, 12(12), 4-20.

Pranowo, K., Achsani, N. A., Manurung, A. H., \& Nuryartono, N. (2010). Determinant of Corporate Financial Distress in an Emerging Market Economy : Empirical Evidence from the Indonesian Stock Exchange 2004-2008. International Research Journal of Finance and Economics, (52), 81-90.

Putra, W. E., \& Lubis, T. A. (2020). What factors Do influence Islamic social reporting (ISR) disclosure? Evidence from Indonesia. International Journal of Recent Technology and Engineering, 8(5), 50-55. https:// doi.org/10.35940/ijrte.e5622.018520.

Qoyum, A., Mutmainah, L., \& Setyono, J. (2017). The Impact of Good Corporate Governance, Company Size and Corporate Social Responsibility Disclosure: Case Study of Islamic Banking in Indonesia. Iqtishadia: Jurnal Kajian Ekonomi Dan Bisnis Islam, 10(1), 130-159.

Research and Development Division Indonesia Stock Exchange. (2018). IDX Fact Book 2018. Jakarta: PT. Bursa Efek Indonesia. Retrieved from www.idx.co.id.
Islamic Social Reporting and Financial Distress 
IQTISHADIA

13,2

176

Ross, S. A. (1973). The Economic Theory of Agency : The Principal's Problem Linked references are available on JSTOR for this article: The Economic Theory of Agency : The Principal's Problem. The American Economic Review, 63(2), 134-139.

Shahab, Y., Ntim, C. G., \& Ullah, F. (2019). The brighter side of being socially responsible: CSR ratings and financial distress among Chinese state and non-state owned firms. Applied Economics Letters, 26(3), 180186. https://doi.org/10.1080/13504851.2018.1450480.

Shrabanti Pal. (2015). Evaluation of Financial Performance in Terms of Financial Ratios- An Empirical Study on Indian Automobile Industry. International Journal of Business Management \& Research (IJBMR), 5(3), 1-8. Retrieved from http://www.tjprc.org/view-archives. php year $=2015 \& i d=32 \&$ jtype $=2 \&$ page $=2$.

Sun, J., Li, H., Huang, Q. H., \& He, K. Y. (2014). Predicting financial distress and corporate failure: A review from the state-of-the-art definitions, modeling, sampling, and featuring approaches. Knowledge-Based Systems, 57, 41-56. https://doi.org/10.1016/j.knosys.2013.12.006.

Sunarsih, U., \& Dahlifah, D. (2020). Islamic Social Reporting Disclosure to Companies Registered in the List of Sharia Securities (DES), 127(Aicar 2019), 56-58. https://doi.org/10.2991/aebmr.k.200309.027.

Syamni, G., Majid, M. S. A., \& Siregar, W. V. (2018). Bankruptcy Prediction Models and Stock Prices of the Coal Mining Industry in Indonesia. Etikonomi, 17(1), 57-68. https://doi.org/10.15408/etk.v17i1.6559.

Triyuwono, I. (2001). Metafora Zakat dan Shari'ah Enterprise Theory sebagai Konsep Dasar dalam Membentuk Akuntansi Syari'ah. Jurnal Akuntansi Dan Auditing Indonesia, 5(2), 131-145.

Widarjono, A. (2018). Ekonometrika: Pengantar dan aplikasinya ( $4^{\text {th }} \mathrm{ed}$.). Yogyakarta: UPP STIM YKPN.

Zmijewski, M. E. (1984). Methodological Issues Related to the Estimation of Financial Distress Prediction Models. Journal of Accounting Research, 22(1984), 59-82. 


\section{Appendix I. Variable Definition and Measurement}

\begin{tabular}{|c|c|}
\hline Variables & Definition and Measurement \\
\hline Dependent Variable & \\
\hline $\begin{array}{l}\text { Modified Altman } \\
\text { Z-Score }\end{array}$ & 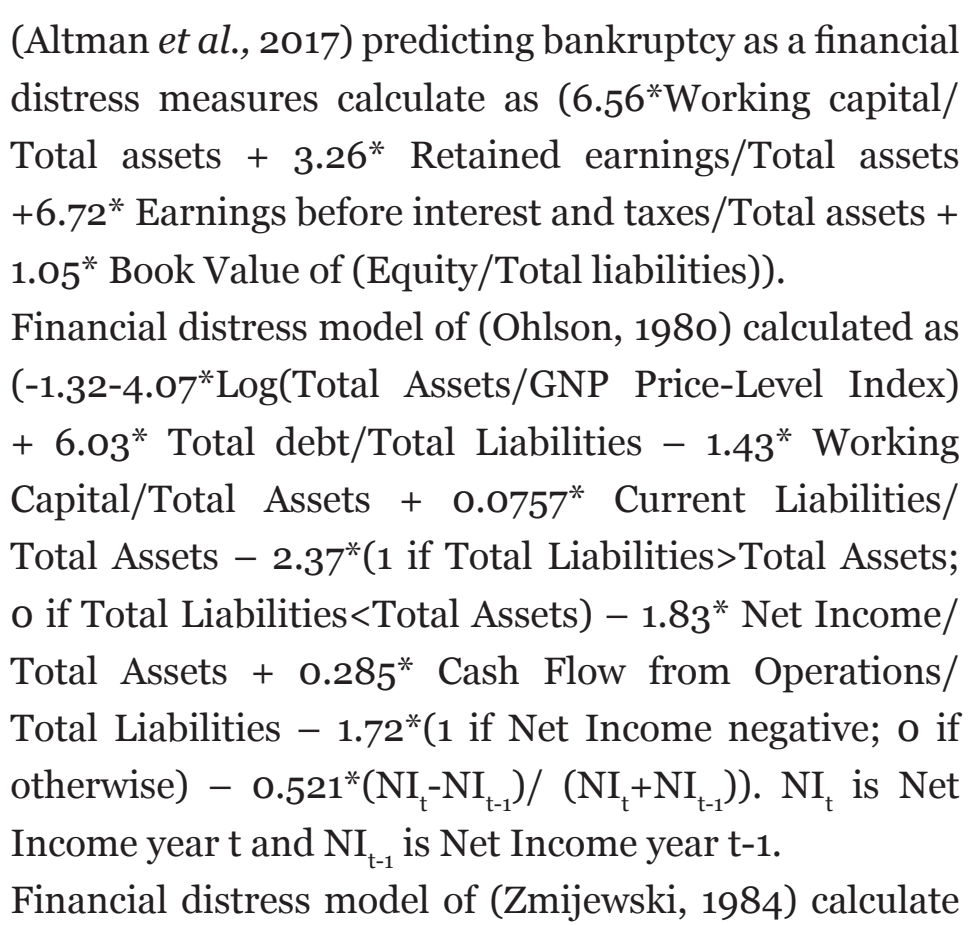 \\
\hline $\begin{array}{l}\text { Zmijewski } \\
\text { Zm-Score }\end{array}$ & $\begin{array}{l}\text { as }\left(\Phi\left(-4.3-4.5^{*} \text { Net income/Total assets }+5 \cdot 7^{*} \text { Total }\right.\right. \\
\text { liabilities/Total assets }-0.004^{*} \text { Current Liabilities/ } \\
\text { Current assets). }\end{array}$ \\
\hline $\begin{array}{l}\text { Independent } \\
\text { Variable }\end{array}$ & \\
\hline
\end{tabular}

Islamic Social

Reporting and

Financial Distress

177 
IQTISHADIA

13,2

178
ISR Index calculate as (Number of Disclosued Items/ Maximum Number of Score) ${ }^{*} 100 \%$.

1. Financial and investment theme (Riba, Gharar, Zakah, insolvent client policy, Current Value Balance Sheet, Value Added Statement)

2. Product and services theme (Environmentally friendly products, Halal product, Safety and quality product, Customer service relationship)

3. Employees theme (Employee characteristics, Education and training, Equal Opportunities, Health and safety, Working environment, Employment of other special-interest-group, Higher echelons in the company perform the congregational prayers with lower and middle level managers, Muslim employees are allowed to perform their obligatory prayers during specific times and fasting during Ramadhan on their working day, Proper place of worship for the employees.

4. Society theme (Donation, Waqf, Qard Hassan, Employee Volunteerism, Education-School Adoption Scheme, Graduate employment, Youth development, Underprivileged community, Children care, Charities, Sponsoring public healh.

5. Environment theme (Conservation of environment, Endangered wildlife, Environmental Pollution, Environmental Education, Environmental Products/ Process related, Environmental Audit/ Independent Verification Statement/Governance, Environmental Management System/Policy.

6. Corporate governance theme (Shariah compliance status, Ownership structure, Board structure-muslim vs non-muslim, Forbidden activities, Anti-corruption policies.

Control Variable

\begin{tabular}{l|l} 
SIZE & Ln Total Assets \\
ROA & Earnings Before Interest and Tax/Total Assets \\
CR & Current Assets/Current Liabilities \\
WCTR & Company Revenue/Working Capital \\
DER & Total Liabilities/Total Equity \\
RETA & Retained Earnings/Total Assets \\
\hline
\end{tabular}

